ШУА-ийн Хими, химийн технологийн хүрээлэн

ЭРДЭМ ШИНжИЛГЭЭНИЙ БУТЭЭЛ

Завхан аймгийн зарим нуурын шаврын судалгааны дүнгээс

\author{
Б.Баяраа ${ }^{1 *}$, Б.Номинцэцэг ${ }^{1}$, Г.Ганзаяа ${ }^{1}$, А.Анхзаяа ${ }^{2}$, Г.Долмаа ${ }^{1}$ \\ ${ }^{1}$ Шинжлэх ухааны академи, Хими, химийн технологийн хүрээлэн, Улаанбаатар 13330, Монгол улс \\ ${ }^{2}{ }^{Э м э э э л т и и ̆ н ~ х ө н г ө н ~ ү и ̆ л д в э р и и ̆ н ~ ү и ̆ л д в э р л э л ~ т е х н о л о г и и ̆ н ~ п а р к, ~ У л а а н б а а т а р, ~ М о н г о л ~ у л с ~}$ \\ *E-mail: bayaraabatnasan@gmail.com
}

\begin{abstract}
Хүлээн авсан: 01.11.2018
Хяналтанд: 03.11.2018

Хэвлэлтэнд авсан: 06.11.2018

Хураангуй: Завхан аймгийн Цагаан нуурын тойром, Цагаан нуурын шавар, шаврын уусмалын ерөнхий үзүүлэлтүүд, органик бодисын агуулга, эрдэс, элементийн найрлагыгхимийн болон физик-химийн орчин үеийн судалгааны аргуудыг (ИК, РД, ICP-AES) ашиглан судлахад Цагаан нуурын шавар нь хүхэртустөрөгчит лаг шаврын ангилалын үзүүлэлттэй, Цагаан нуурын тойрмын шавар нь бялхамал шаврын үзүүлэлтүүдтэй ойролцоо байгаа ч эмчилгээнд хэрэглэх боломжгүй бөгөөд шаврын уусмал нь маш их бохирдолттой гэсэн ангилалаас 5-6 дахин их байгааг илрүүлэн тогтоов. Судалгаанд хамрагдсан 2 нуурын эмчилгээний шаварт нийт 45 элемент бүртгэгдсэнээс зарим макроэлементүүд (Al, Fe, $\mathrm{Mg}, \mathrm{P}, \mathrm{Ba}, \mathrm{K}$ ) далайн ёроолын тунамал хурдасын кларк хэмжээнээс бага, харин $\mathrm{Na}$, Ва агуулга их байна. Цагаан нуурын шаварт гумины бодис $0.71 \%$, липид 0.03 \%, нүүрс-ус 0.04 \%, Цагаан нуурын тойрмын шаварт гумины бодис 0.19 \%, липид 0.29 \%, нүүрс-ус 0.005 \% тус тус агуулгатай байна. Шаврын чөлөөт органик нэгдэл, эрдэстэй холбогдсон болон тэдгээрт шингээгдсэн органик бодисын нийлбэр агуулга Цагаан нуурын шаварт 0.2781 \%, Цагаан нуурын тойрмын шаварт $0.4161 \%$ байгааг судлан тогтоов.
\end{abstract}

Түлхүүр үг: пелоид, гумины бодис, липид, бальнеологи

\section{ОРШИЛ}

Эрт дээр үеэс хүн төрөлхтөний хэрэглэж ирсэн байгалийн чухал хүчин зүйлийн нэг бол эмчилгээний шавар юм. Эмчилгээний шавар нь үүсэл гарал, найрлагаараа ялгаатай биологи, геологи, физикхимийн хүчин зүйлүүдийн зохицолоор нөхцөлдөн үүсч байдаг байгалийн бүтээгдэхүүн юм. Дэлхийн улс орнууд өөрийн нутаг дэвсгэрт байгаа нууруудын шаврыг судлан, тэдгээрийг аль болох зөв зохистой хаягдалгүй ашиглах, ашигласан шавраас биологийн идэвхит бэлдмэл хийх зэрэг ажлуудыг судалгаа шинжилгээний өндөр түвшинд явуулж байна. Эмгүй эмчилгээг чухалчилж байгаа өнөө үед байгалийн эмчилгээний хүчин зүйлийг ашиглах нь эмнэлэг биологи, нийгэм, эдийн засгийн чухал ач холбогдолтой юм. Монгол оронд эмчилгээний шаврын химийн судалгаа 1991 оноос эхлэн нилээд нарийн хийгдэж ирсэн бөгөөд одоогоор 40 гаруй ордын шаврын химийн найрлага, шинж чанар цогцоороо судлагдаад байна. Энэ судалгааны дүнд ямар ордын шаврыг ямар өвчинд, яаж хэрэглэж болох тухай зөвлөмж гарах үндэслэл болж байгаа юм [1]. Монгол орон олон улсын рашааны үнэлэмж хангахуйц 90 гаруй ордтойгоос халуун рашааны 40, хүйтэн рашааны орд 52, байгалийн халуун уур бүхий орд 1, рашаан төст булаг 108, бичил орчин бүхий хүчин зүйлүүд байгаагаас гадна эмчилгээний лаг, наанги, шавартай 50-иад нуур, шаврын орд газрууд байдаг тухай ном, хэвлэлд тусгагдсан байдаг [2].

\section{СУДАЛГААНЫ МАТЕРИАЛ, АРГА ЗУЙ}

Цагаан нуур нь Завхан аймгийн Нөмрөг сумын төвөөс баруун урагш 3-4 км зайд, умард өргөрөгийн $48^{0}$ 56', дорнод уртрагийн $096^{0} \quad 48^{\prime}$ солбицолд далайн

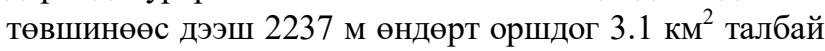
бүхий 3.6 км урт, 1.6 км өргөн, 17 м гүн нуур юм [3]. Цагаан нуурын тойром нь Цагаан нуураасаа 1.0-1.5 км зайд оршдог нуур юм.

Судалгааны дээжийг “Эмчилгээний шаврын ангилал. Техникийн шаардлага” MNS 5848. 2008 -ын [4] дагуу авсан ба шаврын физик-химийн шинж чанар, ерөнхий ба бальнеологийн үзүүлэлтийг MNS 5849:2008 стандартын [5] дагуу тодорхойлов. Үүнд: багтаамжийн жин, сүвэрхэг чанар, үнслэг, дэгдэмхий бодисыг жингийн арга, хөдөлгөөний эсэргүүцэл, наалдамхай чанарыг А.Н.Бунеевийн арга, дулаан дамжуулалтыг Кондратьевын аргаaр, төмрийг комплексометрийн аргаaр, хүхэртустөрөгчийг титрийн аргаар, хүхрийг тунадасжуулах аргаар, органик нүүрстөрөгч $\left(\mathrm{C}_{\text {орг }}\right)$-ийг Тюрины аргаар тус тус тодорхойлов. Эмчилгээний шаврын липидийн агуулгыг MNS 5443:2005 [6] болон гумины бодисын агуулгыг MNS 5442:2005 стандарт [7] аргуудаар, шаврын органик уусгагчид уусдаг чөлөөт ба

DOI: https://doi.org/10.5564/bicct.v0i5.1070 
$<<$ карбонат $>>, \quad<<$ силикат $>>, \quad<<$ сульфид $>>$-ны органик нэгдлүүдийн агуулгыг жингийн аргаар тодорхойлов. Эрдсийн найрлагыг рентген дифрактометрийн багаж, элементийн найрлагыг индукцийн холбоотой плазмын спектрометрын багажийг (ICP-AES) ашиглан тус тус гүйцэтгэсэн.

\section{ҮР ДҮН, ХЭЛЭЛЦУУЛЭГ}

\section{Эмчилгээний шаврын ерөнхий үзүүлэлт}

Завхан аймгийн Цагаан нуур, Цагаан нуурын тойрмын шаврын ерөнхий ба бальнеологийн үзүүлэлтүүдийг “Эмчилгээний шаврын шинж чанарыг тодорхойлох физик химийн аргууд" MNS 5849:2008 стандартын дагуу тодорхойлж Хүснэгт 1-д үзүүлэв.

Судалгаанд авсан 2 нуурын шаврын ерөнхий үзүүлэлтүүдийг тодорхойлоход орчин (pH) 8-9; чийг $21.31-25.18 \%$; хувийн жин $1.87-1.96 \quad$ г/ $\mathrm{cm}^{3}$; хүхэртустөрөгч $0.028-0.096 \%$; Сорг $0.45-0.47 \%$; дэгдэмхий 1.31-8.86\%; үнслэг 90.76-99.66\%; хүхэр $0.0085-0.02 \%$; механик хольц 24.4-26.56\%; хөдөлгөөний эсэргүүцэл 1104.73-6628.38 дин/см- ${ }^{2}$; наалдамхай чанар 3535.14-4860.81 дин/см- ${ }^{2}$; хувийн дулаан багтаамж $0.22-0.47$ кал/г бүхий өргөн хязгаарт хэлбэлзэж байгаa нь тэдгээрийн эргэн тойронд хурдас хуримтлал янз бүр байгааг үзүүлж байгаа юм. Шаврын наалданги чанар хэт бага байвал эмчилгээнд хэрэглэх үед мэдрэлийн хүлээн авууруудад нөлөөлөхдөө харьцангуй учир дутагдалтай байх талтай. Шавруудын наалданги чанарын $\quad$ үзүүлэлтийг практикт хэрэглэхэд зохимжтой дундаж хэмжээтэй (4000-14600 дин/см- ${ }^{2}$ ) харьцуулахад эмчилгээнд хэрэглэхэд тохиромжтой нь хүснэгтээс харагдаж байна. Дээрх ордуудын шавар нь хувийн дулаан багтаамж (0.4-0.8 кал/г) болон дулаанбарих чадвараараа (350-1000 сек) эмчилгээнд хэрэглэхэд шаардагдах стандарт Үзүүлэлтүүдтэй ойролцоо байна [4].

Цагаан нуур, Цагаан нуурын тойрмын шаврын механик хольцын хэмжээ эмчилгээний шаврын стандарт (2-3\%) хэмжээнээс өндөр байна.

Хуснэгт 1. Эмчилгээний шаврын ерөнхий

\begin{tabular}{|c|c|c|}
\hline Ерөнхий үзүүлэлтүүд & $\begin{array}{c}\text { Цагаан } \\
\text { нуур }\end{array}$ & $\begin{array}{l}\text { Цагаан } \\
\text { нуурын } \\
\text { тойром }\end{array}$ \\
\hline$\overline{\Theta н г е}$ & Хар & Саарал \\
\hline 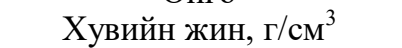 & 1.87 & 1.96 \\
\hline Орчин, рН & 8 & 9 \\
\hline Механик хольц, \% & 24.4 & 26.56 \\
\hline Хүхэртустөрөгч,\% & 0.096 & 0.028 \\
\hline Органик нүүрстөрөгч, \% & 0.47 & 0.45 \\
\hline Чийг, \% & 25.18 & 21.31 \\
\hline Хүхэр, \% & 0.02 & 0.0085 \\
\hline $\begin{array}{l}\text { Дэгдэмхий бодис } \\
\left(550^{\circ} \mathrm{C}\right), \%\end{array}$ & 1.31 & 1.31 \\
\hline Үнслэг $\left(850^{\circ} \mathrm{C}\right), \%$ & 99.63 & 99.66 \\
\hline $\begin{array}{c}\text { Хөдөлгөөний эсэргүүцэл, } \\
{\text { дин } / \mathrm{cm}^{2}}^{2}\end{array}$ & 6628.38 & 1104.73 \\
\hline Наалдамхай чанар, дин/с² & 3535.14 & 4860.81 \\
\hline Дулаан дамжуулалт, сек & 0.033 & 0.034 \\
\hline Дулаан барих чадвар, сек & 303.0 & 294.1 \\
\hline $\begin{array}{c}\text { Хувийн дулаан багтаамж, } \\
\text { кал/Г }\end{array}$ & 0.47 & 0.22 \\
\hline Сүвэрхэг чанар, \% & 0.174 & 0.065 \\
\hline 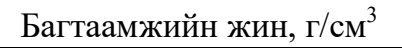 & 2.05 & 2.26 \\
\hline
\end{tabular}

ХУснэгт 2. Эмчилгээний шаврыг олон улсын ангилалд хамруулсан үзУҮлэлт

\begin{tabular}{|c|c|c|c|c|c|c|}
\hline \multirow[b]{2}{*}{ Бүлэг } & \multirow[b]{2}{*}{ Хүлэрт шавар } & \multicolumn{2}{|c|}{ Лаг шавар } & \multirow{2}{*}{$\begin{array}{l}\text { Бялхмал } \\
\text { шавар }\end{array}$} & \multirow{2}{*}{$\begin{array}{c}\text { Цагаан } \\
\text { нуур }\end{array}$} & \multirow{2}{*}{$\begin{array}{c}\text { Цагаан } \\
\text { нуурын } \\
\text { тойром }\end{array}$} \\
\hline & & Сапропель & $\begin{array}{c}\text { Хүхэрт } \\
\text { устөрөгчит }\end{array}$ & & & \\
\hline Өнгө & $\begin{array}{c}\text { Хүрэн, хар, } \\
\text { хүрэн хар }\end{array}$ & $\begin{array}{c}\text { Саарал, } \\
\text { ногоовтор, } \\
\text { хар, хүрэн } \\
\text { ягаан }\end{array}$ & $\begin{array}{l}\text { Хар, саарал, } \\
\text { тосорхог }\end{array}$ & Саарал & Xap & Саарал \\
\hline $\begin{array}{c}\text { Дулаан барих } \\
\text { чадвар, сек }\end{array}$ & $800-1000$ & $800-900$ & $350-450$ & - & 303.0 & 294.1 \\
\hline Чийг, \% & $60-80$ & $80-95$ & $40-61$ & $20-50$ & 25.18 & 21.31 \\
\hline 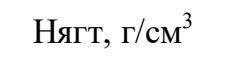 & $1.01-1.5$ & $1.005-1.15$ & $1.1-1.6$ & - & 1.87 & 1.96 \\
\hline Орчин, pH & 2.8 & $6.6-7.5$ & $7.0-9.7$ & 5.0 & 8 & 9 \\
\hline $\begin{array}{c}\mathrm{H}_{2} \mathrm{~S}, \\
\text { байгалийн } \\
\text { шаварт }\end{array}$ & $\begin{array}{c}\text { Агуулагдахгүй } \\
\text { Хааяа } 0.05\end{array}$ & $0.01-0.05$ & $0.05-0.5$ & 0.02 & 0.096 & 0.028 \\
\hline $\begin{array}{c}\text { Органик } \\
\text { бодис, хуурай } \\
\text { жинд }\end{array}$ & $20-98$ & $15-90$ & $1-15$ & $\begin{array}{c}0.5 \\
\text { хүртэл }\end{array}$ & 0.47 & 0.45 \\
\hline
\end{tabular}


Хүснэгт 3. Эмчилгээний шаврын уусмальн үндсэн ҮзҮҮлэлт

\begin{tabular}{|c|c|c|c|}
\hline № & Үзүүлэлтүүд & $\begin{array}{l}\text { Цагаан } \\
\text { нуур }\end{array}$ & $\begin{array}{c}\text { Цагаан } \\
\text { нуурын } \\
\text { тойром }\end{array}$ \\
\hline 1 & Орчин рН & 8 & 9 \\
\hline 2 & 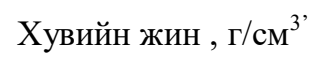 & 1.002 & 1.003 \\
\hline 3 & $\begin{array}{c}\text { Шаврын уусмалын } \\
\text { хуурай үлдэгдэл, г/л }\end{array}$ & 22.5 & 61.7 \\
\hline 4 & $\begin{array}{c}\text { Хлороформд ууссан } \\
\text { бодис, г/л }\end{array}$ & 12.14 & 11.48 \\
\hline
\end{tabular}

Цагаан нуурын шаврын ерөнхий үзүүлэлтийг А.M. Малахов, В.В. Иванов нарын пелоидын олон улсын ангилалын үзүүлэлтүүдтэй (Хүснэгт 2) харьцуулахад Цагаан нуурын шаврын үзүүлэлтүуд нь хүхэртустөрөгчит лаг шаврын үзүүлэлттэй, Цагаан нуурын тойрмын шаврын үзүүлэлтүүд нь бялхамал шаврын ангилалын үзүүлэлттэй илүү ойр байгаа ч эмчилгээнд хэрэглэхэд учир дутагдалтай болох нь дараах шинжилгээний дүнгүүдээр батлагдаж байгаа болно.

Шаврын уусмалын шинж чанар. Шавраас ялган авсан шаврын уусмалын ерөнхий үзүүлэлтүүдийг $\mathrm{pH}$, хувийн жин, хуурай үлдэгдэл, хлороформд уусах бодисын гарц зэрэг үзүүлэлтүүдээр тодорхойлж Хүснэгт 3-д үзүүлэв. Судалгаанд авсан хоёр нуурын шавраас ялган авсан уусмалын ерөнхий үзүүлэлтүүдийг тодорхойлоход орчин (рH) 8-9;

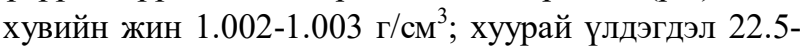
61.7 г/л; хлороформд ууссан бодисын гарц 11.4811.48 г/л байна. Энэ нь тухайн нуурын усанд маш их хэмжээний органик болон органик бус бодис ууссан байгааг харуулж байна. Эдгээр ууссан бодисын найрлага шаврын уусмалын задлан шинжилгээнээс илүҮ тодорхой харагдаж байгаа юм (Хүснэгт 4). Цагаан нуурын болон Цагаан нуурын тойрмын шаврын уусмалын химийн найрлагыг ГазарзүйГеоэкологийн хүрээлэнгийн усны лабораторид тодорхойлуулсан дүнг нэгтгэн Хүснэгт 4-д үзүүлэв. Цагаан нуур, Цагаан нуурын тойрмын шаврын уусмалын задлан шинжилгээний дүнгээс харахад натри, кали, магнийн катион, хлор, сульфат ионы агуулга маш өндөр, ерөнхий хатуулаг их бохирдолттой ангилалаас 6 дахин их байв. Ялангуяа Цагаан нуурын тойрмын уснаас мал уухаар үхдэг гэсэн малчдын хүсэлтийг харгалзан дээж авч хийсэн болно. Шинжилгээгээр эдгээр нууруудын ус нь химийн бүрэлдхүүнээрээ гидрокарбонатын ангийн, натрийн бүлгийн, 1-р төрлийн, Цагаан нуурын ус

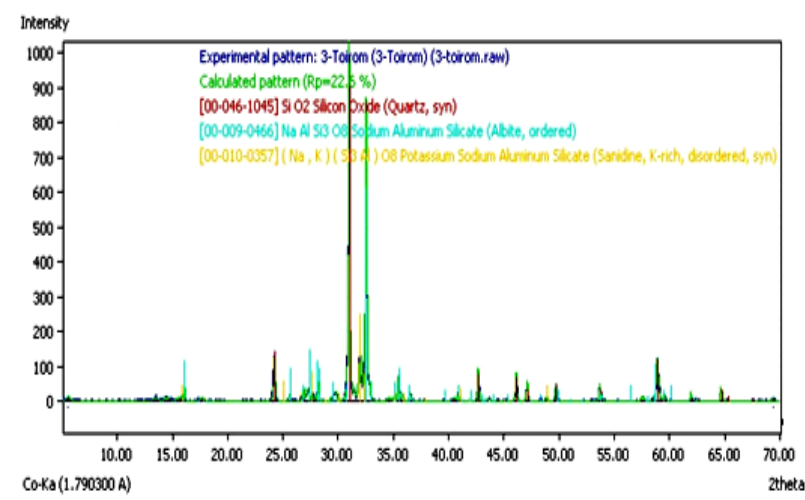

Зураг 1. Цагаан нуурын тойрмын иаврын рентгенграмм

чанарын хувьд давсархаг, зөөлөвтөр сул шүлтлэг, органик бохирдолт ихтэй ус байна. Цагаан нуурын тойрмын усны чанарын хувьд шорвог, маш хатуу ус

Хүснэгт 4. Цагаан нуурын тойром болон Цагаан нуурын шаврын уусмальн химийн найрлага

\begin{tabular}{|c|c|c|c|c|c|c|c|}
\hline Үзүүлэлтүуд & $\begin{array}{c}\mathbf{I} \\
\text { Маш } \\
\text { цэвэр }\end{array}$ & $\frac{\text { II }}{\text { Цэвэр }}$ & $\begin{array}{c}\text { III } \\
\text { Бохирдолт } \\
\text { багатай }\end{array}$ & $\begin{array}{c}\text { IV } \\
\text { Бохирдолт } \\
\text {-той } \\
\end{array}$ & $\begin{array}{c}\mathbf{V} \\
\begin{array}{c}\text { Иx } \\
\text { бохир }\end{array} \\
\end{array}$ & $\begin{array}{c}\text { Цагаан } \\
\text { нуур }\end{array}$ & $\begin{array}{l}\text { Цагаан } \\
\text { нуурын } \\
\text { тойром }\end{array}$ \\
\hline Орчин, pH & $6.5-8$ & $6.5-8.5$ & $6.0-8.5$ & $6.0-9$ & $6.5-9.5$ & 8.7 & 7.8 \\
\hline $\begin{array}{c}\text { Ерөнхий } \\
\text { хатуулаг, мг/л }\end{array}$ & $<10$ & 15 & 20 & 30 & $40<$ & 61.3 & 266.7 \\
\hline $\mathrm{Cl}^{-}$, мг/л & $<50$ & 150 & 250 & 350 & $500<$ & 127.8 & 745.5 \\
\hline $\mathrm{SO}_{4}^{--}$, мг/л & $<50$ & 100 & 200 & 300 & $400<$ & 40.0 & 350.0 \\
\hline $\mathrm{NO}_{2}^{-}, \mathrm{M \Gamma} / л$ & $<0.002$ & 0.005 & 0.02 & 0.05 & $0.1<$ & - & - \\
\hline $\mathrm{NO}_{3}^{-}, \mathrm{Mг} / л$ & $<1$ & 3 & 5 & 10 & $20,0<$ & 8.0 & - \\
\hline $\mathrm{CO}_{3}^{--}, \mathrm{мг} / л$ & - & - & - & - & - & 69.0 & - \\
\hline $\mathrm{HCO}_{3}^{-}, \mathrm{M \Gamma} / л$ & - & - & - & - & - & 1049.2 & 4160.2 \\
\hline $\mathrm{Na}^{+}+\mathrm{K}^{+}, \mathrm{мг} / л$ & - & - & - & - & - & 452.2 & 1756.6 \\
\hline $\mathrm{Ca}^{++}, \mathrm{мг/л}$ & $<45$ & 90 & 150 & 200 & $300<$ & 20.0 & 60.1 \\
\hline $\mathrm{Mg}^{++}, \mathrm{мг} / л$ & $<15$ & 30 & 50 & 100 & $200<$ & 41.3 & 206.7 \\
\hline $\mathrm{NH}_{4}{ }^{+}, \mathrm{мг/л}$ & $<0.02$ & 0.05 & 0.1 & 0.3 & $0.5<$ & - & 2.1 \\
\hline
\end{tabular}




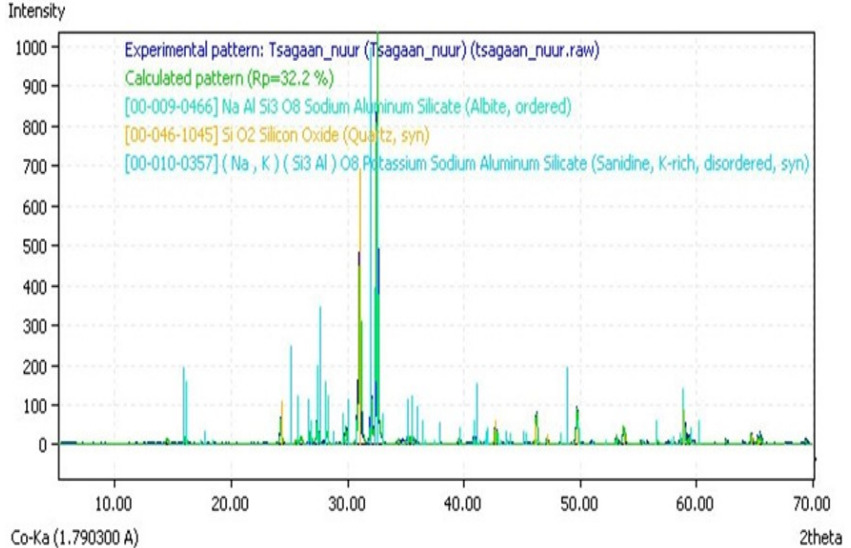

Зураг 2. Цагаан нуурын шаврын рентгенграмм байна. УГ усыг “Гадаргын усны цэврийн зэргийн ангиллын норм”-той харьцуулахад исэлдэх чанар, магни, хлор, ууссан бодисуудын хуурай үлдэгдэл, аммоний ион, физик шинж зэрэг үзүүлэлтүүдээрээ “их бохирдолттой” гэсэн ангилалд хамаарч байна [8].

Цагаан нуур, Цагаан нуурын тойрмын шаврын элементийн ба эрдсийн агуулга. Судалгаанд хамрагдсан нууруудын шаврыг индукцийн холбоотой плазмын спектрометр багажны тусламжтай элементийн агуулгыг тодорхойлж далайн ёроолын тунамал хурдасны кларк хэмжээтэй харьцуулж, дүнг Хүснэгт 5-д нэгтгэв.

Цагаан нуур, Цагаан нуурын тойрмын шаврыг

ХУснэгт 5. Шаврын элементийн агуулга, \%

\begin{tabular}{|c|c|c|c|c|}
\hline \multirow{2}{*}{\multicolumn{2}{|c|}{ Тодорхойлсон элементүүд }} & \multirow{2}{*}{ Кларк хэмжээ, \% } & \multicolumn{2}{|c|}{ Агуулга, \% (хуурай шаварт) } \\
\hline & & & Цагаан нуур & Цагаан нуурын тойром \\
\hline \multirow{8}{*}{ Макро элементүҮд } & $\mathrm{Al}$ & 7.8 & 5.81 & 6.03 \\
\hline & $\mathrm{Fe}$ & 8.65 & 0.85 & 1.11 \\
\hline & $\mathrm{Ca}$ & 7.6 & 1.27 & 1.47 \\
\hline & $\mathrm{Mg}$ & 4.6 & 0.26 & 0.41 \\
\hline & $\mathrm{Ba}$ & 0.033 & 0.068 & 0.065 \\
\hline & $\mathrm{Na}$ & 1.8 & 2.3 & 2.38 \\
\hline & $\mathrm{K}$ & - & 2.4 & 2.25 \\
\hline & $\mathrm{P}$ & - & 0.02 & 0.067 \\
\hline \multirow{8}{*}{ Микро элементүүд } & $\mathrm{Mn}$ & 0.15 & 0.0191 & 0.0242 \\
\hline & $\mathrm{Cu}$ & 0.0087 & 0.0013 & 0.001 \\
\hline & $\mathrm{Cr}$ & 0.017 & 0.001 & - \\
\hline & Co & 0.0048 & 0.0004 & 0.0001 \\
\hline & $\mathrm{V}$ & 0.025 & 0.0021 & 0.0032 \\
\hline & $\mathrm{Zn}$ & 0.0105 & 0.0019 & 0.002 \\
\hline & $\mathrm{Ni}$ & 0.013 & 0.0009 & 0.0008 \\
\hline & $\mathrm{Pb}$ & 0.025 & 0.0012 & 0.0013 \\
\hline \multirow{2}{*}{ ГХЭ } & $\mathrm{Ce}$ & 0.007 & - & $<0.005$ \\
\hline & $\mathrm{La}$ & 0.003 & 0.001 & 0.001 \\
\hline \multirow{4}{*}{ Хүнд хортой } & $\bar{U}$ & 0.00026 & $<0.001$ & $<0.001$ \\
\hline & $\mathrm{W}$ & - & $<0.001$ & $<0.001$ \\
\hline & Th & 0.0013 & $<0.002$ & $<0.002$ \\
\hline & As & - & $<0.0005$ & $<0.0005$ \\
\hline \multirow{6}{*}{ Өнгөт металл } & $\mathrm{Sn}$ & 0.0002 & - & $<0.001$ \\
\hline & $\mathrm{Ga}$ & 0.0017 & 0.001 & 0.001 \\
\hline & $\mathrm{Ti}$ & 1.38 & 0.1 & 0.18 \\
\hline & $\mathrm{Li}$ & - & - & 0.002 \\
\hline & Mo & 0.0003 & $<0.0001$ & $<0.0001$ \\
\hline & $\mathrm{Ag}$ & $1.1 * 10^{-5}$ & $<0.00005$ & $<0.00005$ \\
\hline \multirow{15}{*}{ Бусад } & $\mathrm{Bi}$ & 0.00002 & $<0.0002$ & $<0.0002$ \\
\hline & $\mathrm{Nb}$ & 0.0018 & - & 0.0005 \\
\hline & $\mathrm{Rb}$ & 0.0078 & - & 0.009 \\
\hline & $\mathrm{Sb}$ & 0.05 & $<0.0005$ & $<0.0005$ \\
\hline & $\mathrm{Sc}$ & 0.001 & 0.0004 & 0.0004 \\
\hline & $\mathrm{Sr}$ & 0.014 & 0.0289 & 0.0334 \\
\hline & $\mathrm{Ta}$ & 0.00024 & - & $<0.001$ \\
\hline & $\mathrm{Y}$ & 0.0026 & - & 0.001 \\
\hline & $\mathrm{Zr}$ & - & - & 0.004 \\
\hline & $\mathrm{Tl}$ & - & $<0.001$ & $<0.001$ \\
\hline & $\mathrm{Te}$ & - & - & $<0.001$ \\
\hline & $\mathrm{Se}$ & - & - & $<0.001$ \\
\hline & $\mathrm{Hg}$ & - & - & 0.001 \\
\hline & $\mathrm{Be}$ & - & 0.068 & 0.00015 \\
\hline & $\mathrm{S}$ & - & 0.07 & 0.10 \\
\hline
\end{tabular}


Хүснэгт 6. Шаврын бүлэг органик нэгдлүҮдийн агуулга

\begin{tabular}{|c|c|c|c|c|}
\hline \multirow{4}{*}{ Бодис } & \multicolumn{2}{|c|}{ Цагаан нуур } & \multicolumn{2}{|c|}{ Цагаан нуурын тойром } \\
\hline & \multicolumn{4}{|c|}{ Нийт органик бодис, \% } \\
\hline & \multicolumn{2}{|c|}{0.81} & \multicolumn{2}{|r|}{0.77} \\
\hline & $\begin{array}{c}\text { Хуурай шаварт, } \\
\%\end{array}$ & $\begin{array}{c}\text { Нийт органик бодист, } \\
\%\end{array}$ & $\begin{array}{c}\text { Хуурай шаварт, } \\
\%\end{array}$ & $\begin{array}{c}\text { Нийт органик бодист, } \\
\%\end{array}$ \\
\hline Гумины бодис & 0.71 & 87.65 & 0.19 & 24.68 \\
\hline Липид & 0.03 & 3.7 & 0.29 & 37.66 \\
\hline Нүүрс-ус & 0.04 & 4.93 & 0.005 & 0.65 \\
\hline $\begin{array}{c}\text { Органик } \\
\text { уусгагчдад уусдаг } \\
\text { бодис }\end{array}$ & 0.0837 & 10.33 & 0.06 & 7.79 \\
\hline
\end{tabular}

индукцийн холбоотой плазмын спектрометр багажаa (ICP-AES) шинжлүүлэхэд макро элементүүдийн хувьд төмөр (Fe), кальци (Ca), магни $(\mathrm{Mg})$; микро элементүүдийн хувьд манган (Mn), хром (Cr), кобальт (Co), цайр $(\mathrm{Zn})$, никель $(\mathrm{Ni})$; газрын ховор элементүүдээс цери $(\mathrm{Ce})$, лантан $(\mathrm{La})$; өнгөт металлуудаас галли (Ga), титан (Ti) зэрэг элементүүд нь далайн ёроолын тунамал хурдас дахь кларк хэмжээнээс тус тус бага агуулгатай байна. Судалгаанд авсан нууруудын шаврын дээжийг хатааж нунтаглан эрдсийн найрлагыг рентген
кварц-SiO 2 болон альбит- $\mathrm{NaAlSi}_{3} \mathrm{O}_{8}$, санидин-(Na, K) $\left(\mathrm{AlSi}_{3}\right) \mathrm{O}_{8}$ зэрэг эрдсүүд давамгайлж байна. Дээрх ордуудын шавар нь эрдсийн найрлагаараа холимог эрдэст шаврын ангилалд хамаарагдаж байна.

Шаврын органик бүрэлдэхүүний агуулга. Цагаан нуур, Цагаан нуурын тойрмын нуурын шаварт биологийн өндөр идэвхитэй органик нэгдэл болох гумины бодис, липид, нүүрсусны гарцыг тодорхойлж Хүснэгт 6-д харуулав. Цагаан нуур, Цагаан нуурын тойрмын шаварт органик уусгагчидад уусдаг органик нэгдлүүдээс гадна нүүрс-ус 0.005-0.04\%, липид 0.03-

Хүснэгт 7. Шаврын чөлөөт органик бодисын агуулга

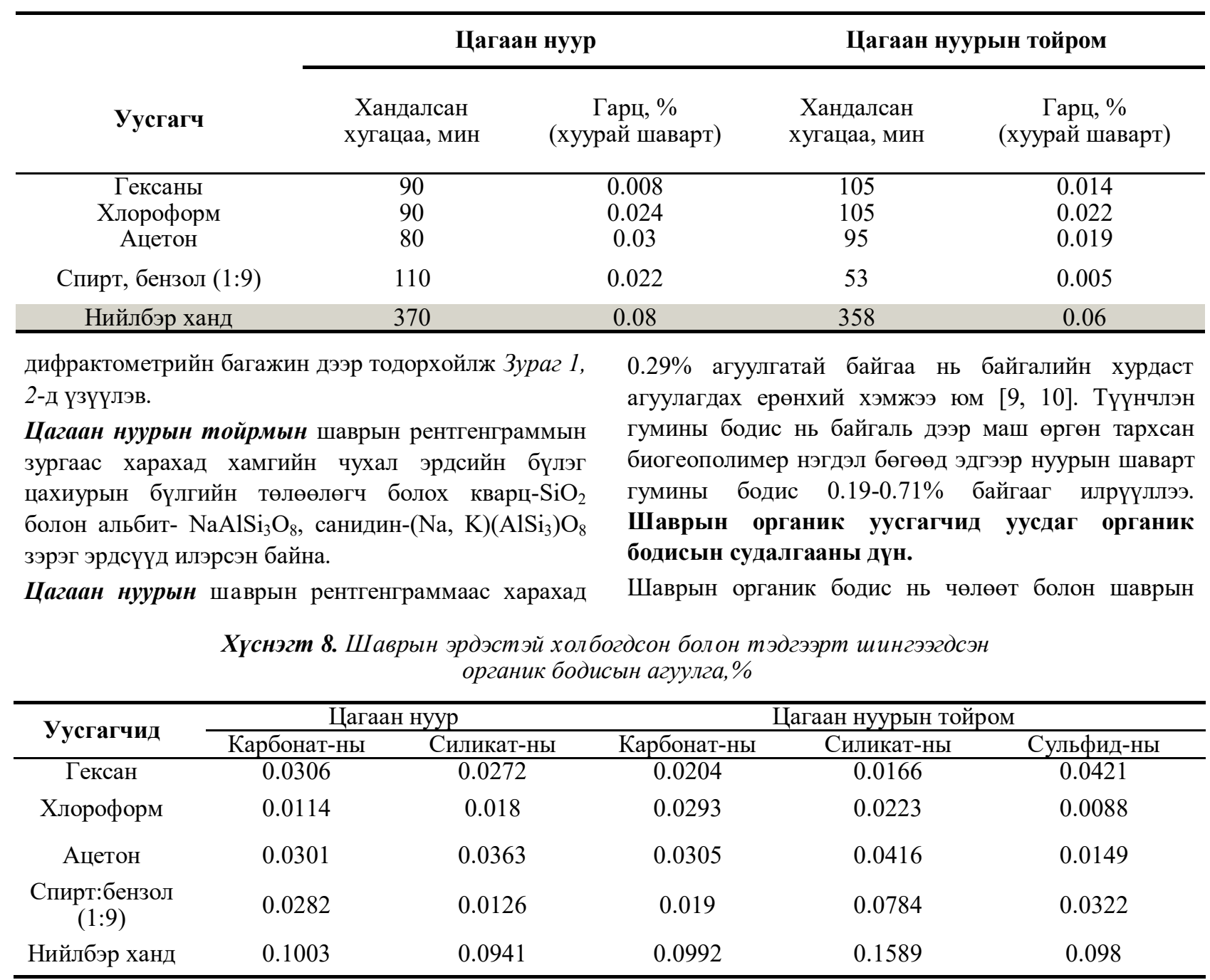


эрдэс хэсэгтэй холбогдсон ба тэдгээрт шингээгдсэн байдлаар оршдог. Шавар дахь чөлөөт органик бодисын агуулгыг гексан, хлороформ, ацетон, спирт: бензол (1:9) зэрэг органик уусгагчидаар дараалуулан хандлан ялгаж хуурай үлдэгдлийн гарцыг жингийн аргаар тодорхойлж $Х$ Үснэт 7-д нэгтгэв. Судалгааны дүнгээс харахад чөлөөт органик нэгдлийн агуулга

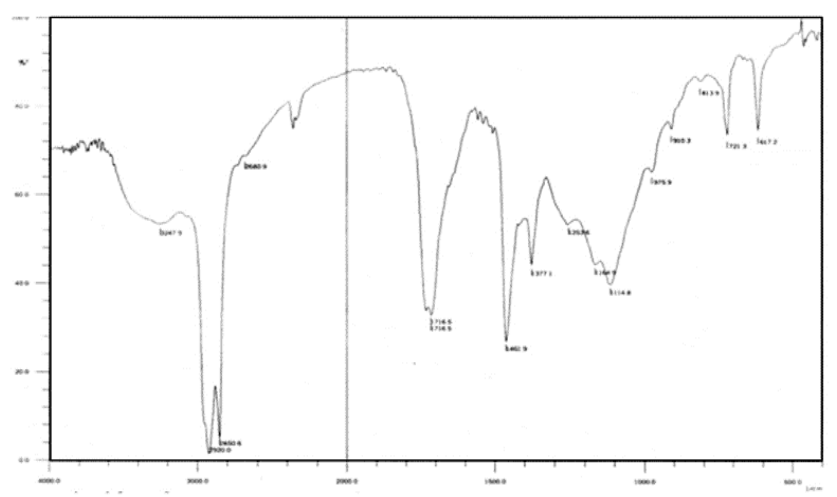

Зураг 3. Цагаан нуурын шаврын чөлөөт органик нэгдлийн хлорформд уусдаг хэсгийн нил улаан туяаны спектрограмм

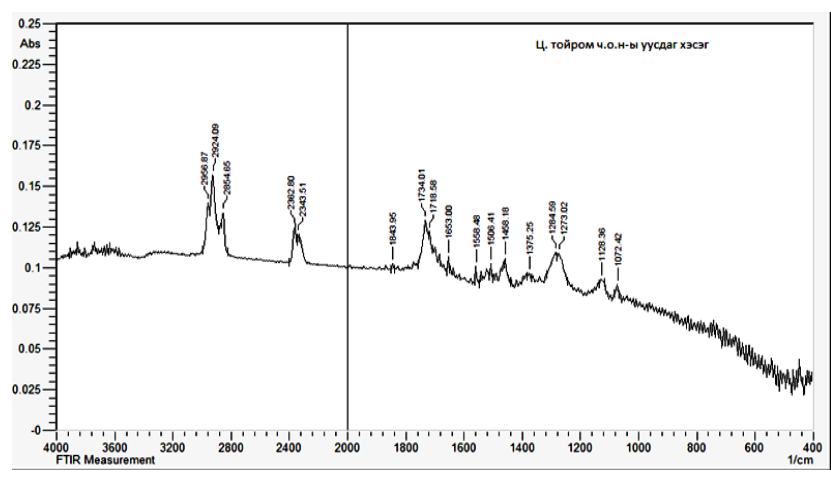

Зураг 4. Цагаан нуурын тойрмын шаврын чөлөөт органик нэгдлийн хлорформд уусдаг хэсгийн

Цагаан нуурын шаварт $0.08 \%$, Цагаан нуурын тойрмын шаварт $0.06 \%$ тус тус гарсан байна.

Цагаан нуурын шавар нь ацетонд харьцангуй их хандлагдсанаас үзвэл туйлт органик нэгдлүүд давамгайлж байгаа нь харагдаж байна. Шаврын эрдэстэй холбогдсон ба тэдгээрт шингээгдсэн органик нэгдлийн агуулгыг чөлөөт органик бодисыг ялгасан дээжийг эрдсийн хүчлүүдээр дараалан задалж, туйлт болон туйлгүй уусгагчидаар дээрхийн адил хандалж, <<карбонат $>>$, <<силикат $>>$ ба $<<$ сульфид $>>$-ны органик нэгдлүүдийн агуулгыг жингийн аргаар тодорхойлж дүнг Хүснэгт 8-д нэгтгэв.

Хүснэгтэнд нэгтгэсэн дүнгээс харахад нийлбэр ханд нь Цагаан нуурын шаварт <Карбонатын> $0.1003 \%$, $<$ Силикатын $>0.0815 \%$, Цагаан нуурын тойрмын шаварт $<$ Карбонат $>$-ны $\quad 0.0992 \%, \quad<$ Силикат $>$-ны $0.1589 \%,<$ Сульфид>-ны $0.0658 \%$ тус тус агуулагдаж байгаа бөгөөд Цагаан нуурын шаварт карбонатны эрдэстэй, Цагаан нуурын тойрмын шаварт силикатны эрдэстэй холбогдсон органик нэгдэл их байгаа нь эдгээр эрдсүүдийн бүтэцтэй холбоотой.

Шаврын чөлөөт органик бодисын нил улаан туяаны спектрийн үр дүн.

Завхан аймгийн Цагаан нуурын тойром, Цагаан нуурын шаврыг туйлт болон туйлгүй уусгагчдаар дараалан хандалсан чөлөөт органик нэгдлийн хандын хуурай үлдэгдлийн хлорформд уусдаг хэсэгт нил улаан туяаны спектрийн судалгааг ШУАФТХүрээлэн болон ШУТИС-д хийсэн дүнг Зураг 3, 4 -д үзүүлэв.

Цагаан нуурын шаврын чөлөөт органик нэгдлийн хлорформд уусдаг хэсгийн нил улаан туяаны спектрт дараах шингээлтийн зурвасууд илрэв. Нил улаан туяаны спектрийн $3247.9 \mathrm{~cm}^{-1}$ мужид димер, тример болон полиассоциацлагдсан устөрөгчийн холбоо үүсгэсэн байж болох ОН бүлгийн шингээлт; 2920.0 $\mathrm{cm}^{-1}, 2850.6 \mathrm{~cm}^{-1}$ мужид алифатик $\mathrm{CH}, \mathrm{CH}_{2}, \mathrm{CH}_{3}$ бүлгийн шингээлт; $2680.9 \mathrm{~cm}^{-1}$ мужид альдегидын $\mathrm{CH}$ бүлгийн сул шингээлт; $1716.5 \mathrm{~cm}^{-1}$ мужид нийлмэл эфирийн $\mathrm{C}=\mathrm{O}$ эрчмийн өсөлт бүхий хүчтэй шингээлт; $1461.9 \mathrm{~cm}^{-1}$ мужид альфатик нүүрсустөрөгчид харгалзах ассимметр деформацийн хэлбэлзэл; 1377.1 $\mathrm{cm}^{-1}$ мужид $\mathrm{CH}_{3}, \mathrm{CH}_{2}$, амины $\mathrm{C}-\mathrm{N}$ бүлэгт хамааруулж болох шингээлт; $1253.6 \mathrm{~cm}^{-1}$ мужид $\mathrm{C}-\mathrm{O}$ бүлгийн валентын хэлбэлзэл; $1164.6 \mathrm{~cm}^{-1}, 1114 \mathrm{~cm}^{-1}$ мужид спирт, карбон хүчил, эфирийн $(\mathrm{C}-\mathrm{O})$ бүлгийн шингээлт; $617.2 \mathrm{~cm}^{-1}-975.9 \mathrm{~cm}^{-1}$ мужид ароматик цагирагт хамаарагдах $\mathrm{C}-\mathrm{H}$ холбооны деформацийн хэлбэлзэлийн шингээлтүүд тус тус илэрсэн байна. Цагаан нуурын тойрмын шаврын чөлөөт органик нэгдлийн хлорформд уусдаг хэсгийн нил улаан туяаны спектрт дараах шингээлтийн зурвасууд илэрсэн. Нил улаан туяаны спектрийн 2956.87$2854.65 \mathrm{~cm}^{-1}$ мужид алифатик $\mathrm{CH}, \mathrm{CH}_{2}, \mathrm{CH}_{3} ; 2343.51$ $2362.80 \mathrm{~cm}^{-1}$ мужид альдегидын СН бүлгийн сул шингээлт; 1506.41-1843.95 $\mathrm{cm}^{-1}$ мужид шугаман альдегидад $\mathrm{C}=\mathrm{O}$ хамаарагдах кетон, карбон хүчил, эфирийн бүлгийн шингээлт; $1458.18 \mathrm{~cm}^{-1}$ мужид альфатик нүүрсустөрөгчид харгалзах ассимметр деформацийн хэлбэлзэл; 1273.02- $1375.25 \mathrm{~cm}^{-1}$ мужид $\mathrm{CH}_{3}, \mathrm{CH}_{2}$, амины C-N бүлэгт хамааруулж болох шингээлт; $1128.36 \mathrm{~cm}^{-1}$ мужид спирт, карбон хүчил, эфирийн (С-О) бүлгийн шингээлт; $1072.42 \mathrm{~cm}^{-1}$ мужид спиртийн бүлгийн шингээлтүүд тус тус илэрсэн нь шаврын чөлөөт органик нэгдэл нь нарийн нийлмэл бүтэцтэй болох нь тогтоогдлоо.

\section{ДУГНЭЛТ}

Завхан аймгийн Цагаан нуурын тойром, Цагаан нуурын шаврын ерөнхий ба бальнеологийн үзүүлэлтүүд, органик бодисын агуулга, эрдэс, элементийн найрлагыг химийн болон физик-химийн орчин үеийн судалгааны аргуудыг (ИК, РД, ICРAES) ашиглан тодорхойлов.

Судалгаанд хамрагдсан нууруудын шаврын органик бүрэлдэхүүнд гумины бодис, нүүрс-ус, липид, органик уусгагчидад уусдаг бодис (чөлөөт болон 
эрдэстэй холбогдсон ба тэдгээрт шингээгдсэн)-ын нийт агуулга нь органик нүүрстөрөгчийн агуулга дээр үндэслэн тооцоолсон дүнтэй ерөнхийдөө тохирч байна. Дээрх ордуудын шавар нь эрдсийн найрлагаараа холимог эрдэст шаврын ангилалд хамаарагдаж байна.

Цагаан нуурын шавар нь пелоидын олон улсын ангилалын Үзүүлэлтүдтэй харьцуулахад хүхэртустөрөгчит лаг шаврын ангилалын үзүүлэлттэй, Цагаан нуурын тойрмын шавар нь бялхамал шаврын үзүүлэлтүүдтэй ойролцоо байгаа ч эмчилгээнд хэрэглэх боломжгүй бөгөөд шаврын уусмал нь маш их бохирдолттой гэсэн ангилалаас ч 5-6 дахин их байгааг илрүүлэн тогтоов.

\section{АШИГЛАСАН МАТЕРИАЛ}

1. Г.Долмаа, “Эмчилгээний шавар байгалийн гайхамшигт бүтээгдэхүун”. Улаанбаатар. 2012oн.

2. Рашаан сувилльг хөгжүүлэх үндэсний хөтөлбөр Улаанбаатар. 2003. “Батпринтинг” ХХК. х.1-2
3. Г.Даваа, “Монгол орны гадаргын усны горим, нөөц’. УБ. 2015

4. Г.Долмаа, Б.Намбар, Ш.Цэрэнпил “Эмчилгээний шаврын ангилал. Техникийн шаардлага" MNS 5848. 2008.

5. Г.Долмаа, Ө.Угтахбаяр, Ш.Цэрэнпил. “Эмчилгээний шаврын шинж чанарыг тодорхойлох физик химийн аргууд”. MNS 5849:2008.

7. Г.Долмаа, Ө.Угтахбаяр, Ш.Цэрэнпил “Эмчилгээний лаг шавраас липидийг ялгах арга", MNS 5443:2005.

8. Г.Долмаа, Ш.Цэрэнпил, Ө.Угтахбаяр “Эмчилгээний шавраас гумины бодисыг ялгах арга", MNS 5442:2005

9. Байгаль орчны сайд, Эрүүл мэнд, нийгмийн хамгааллын сайдын 1997 оны 143/A/352 тоот тушаалын 3-p хавсралт, 4-p хавсралт “Гадаргын усны цэврийн зэргийн норм".

10. Э.Т.Дегенс. Геохимия осадочных образований. Изд-во “Мир”, 1967 г. С. 81-113.

\title{
Investigation of peloid from some lake in Zavkhan province
}

\author{
B.Bayaraa $^{1 *}$, B.Nomintsetseg $^{1}$, G.Ganzaya $^{1}$, A.Ankhzaya $^{2}$, G.Dolmaa $^{1}$ \\ ${ }^{1}$ Institute of Chemistry and Chemical Technology, Mongolian Academy of Sciences, Ulaanbaatar 13330, Mongolia \\ ${ }^{2}$ Emeelt Light Industrial Production and Technology Park, Ulaanbaatar, Mongolia \\ *E-mail: bayaraabatnasan@gmail.com
}

\begin{tabular}{|c|c|}
\hline Received: 01.11.2018 & Revised: 03.11.2018 \\
\hline
\end{tabular}

\begin{abstract}
The purpose of study was to determine chemical composition and organic matter of peloids from lakes located named as Tsagaan Lake and toirom of Tsagaan Lake in Zavkhan province by chemical and modern physicochemical methods, including (X-ray, IR and ICP-AES). From the result, peloid from Tsagaan Lake was identified that peloid belongs to silt sulphide muddy type whereas characterization of peloid from toirom of Tsagaan Lake was almost similar with peloid knoll, but it is not possible to use the treatment and peloid solution was 5 to 6 times higher than the category of much pollutant. 45 elements determined in two Lakes peloid's samples. The content of some macro elements ( $\mathrm{Al}, \mathrm{Fe}, \mathrm{Mg}, \mathrm{P}, \mathrm{Ba}$ and $\mathrm{K}$ ) were lower than Clark elements of sea bottom sediment whereas the content of $\mathrm{Na}, \mathrm{Ba}$ were higher than it. Lipid and carbohydrate contains were between $0.03-0.29 \%$, and $0.005-0.04 \%$. Humic substances content varied between $0.19 \%-0.71 \%$ in these peloids. Organic matters, which are free, associated with minerals and absorbed extracted in peloids using non-polar and polar solvents; yield of total extract in peloids were $0.2781 \%, 0.4161 \%$ respectively.
\end{abstract}

Keywords: peloid, humic substance, lipid, balneological.

(C) The Author(s). 2018 Open Access This article is distributed under the terms of the Creative Commons Attribution 4.0 International License (https://creativecommons.org/licenses/by/4.0/), which permits unrestricted use, distribution, and reproduction in any medium, provided you give appropriate credit to the original author(s) and the source, provide a link to the Creative Commons license, and indicate if changes were made.

DOI: $\underline{\text { https://doi.org/10.5564/bicct.v0i5.1070 }}$ 